Mohsen Karimi ${ }^{1,2, *}$

Jose L. Diaz de Tuesta ${ }^{1,2}$

Carmem N. d. P. Gonçalves ${ }^{2}$

Helder T. Gomes ${ }^{1,2}$

Alírio E. Rodrigues ${ }^{1}$

José A. C. Silva ${ }^{1,2, *}$
Supporting Information available online

\section{Compost from Municipal Solid Wastes as a Source of Biochar for $\mathrm{CO}_{2}$ Capture}

Increasing greenhouse gas emissions contributing to the global climate change are a major concern of environmental protection. Developing adsorbents from lowcost and renewable resources is an attractive strategy. On the other hand, the high capacity of production rates of municipal solid waste, besides high methane emissions, is the origin of some eco-systemic challenges. The combination of the two environmental problems is considered by introducing the compost from a mechanical biological treatment of municipal solid wastes as a low-cost source of adsorbent for $\mathrm{CO}_{2}$ capture. The obtained compost was thermally and chemically activated and the $\mathrm{CO}_{2}$ adsorption capacities of prepared samples were evaluated. Samples prepared sequentially with sulfuric acid and heated at $800^{\circ} \mathrm{C}$ and vice versa, respectively, had the highest uptake capacities and were comparable with commercial adsorbents.

Keywords: Biochar, Central composite design, $\mathrm{CO}_{2}$ capture, Municipal solid waste

Received: February 14, 2019; revised: March 06, 2020, accepted: March 06, 2020

DOI: 10.1002/ceat.201900108

\section{Introduction}

\subsection{Global Warming and $\mathrm{CO}_{2}$ Capture}

Global warming is one of the major concerns of mankind in the recent decades, which needs significant attempts to reduce the emission of greenhouse gases (GHGs) [1]. Among all GHGs, $\mathrm{CO}_{2}$ plays the main role, contributing to several adverse effects on the ecosystem and environment, and if the current dangerous level of the GHGs is not controlled, it can face the life on this planet with serious challenges. The coal- and natural gas-fired power plants released $11.1 \mathrm{Gt}$ of $\mathrm{CO}_{2}$, nearly $30 \%$ of the total global emissions in 2012 [2,3]. In this way, the combustion of coal, also oil and natural gas industries including naphtha refineries $[4,5]$ and petrochemical complexes $[6,7]$, are the main industrial sources of $\mathrm{CO}_{2}$ emissions $[8,9]$. As consequence of these industrial activities, the $\mathrm{CO}_{2}$ percentage exceeded $50 \mathrm{ppm}$ in the atmosphere from the maximum allowable level in the pre-industrial period until now (280-400 ppm) [10,11]. Thus, strict policies, better strategies, and more attention for capturing and sequestering $\mathrm{CO}_{2}$ are required.

\subsection{Solid Waste Management}

Municipal solid waste (MSW) is a term usually referred to the unwanted or useless solid materials originating from the combined residential, industrial, and commercial activities in urban areas $[12,13]$. The capacity of the MSW production was 2.01 billion metric tons per year in 2018 , while this amount is expected to increase to around 3.40 billion metric tons per year in 2050 [14]. Also, it is estimated that $\sim 13.5 \%$ of today's waste is recycled and $5.5 \%$ is composted, while $40 \%$ of worldwide generated waste is not properly managed. Therefore, rich countries, including the United States, Canada, and members of the European Union, having $16 \%$ of global population, are responsible for more than $34 \%$ of the world's waste [14]. To reduce the destructive effects of this huge amount of solid wastes, a large number of research activities have focused on the development of new waste management strategies. There are some main treatment techniques for solid wastes, such as employing extremely high temperatures [12], dumping on the land [15], and also applying biological processes to treat the wastes and produce compost, which is one of the most popular strategies $[12,15]$.

\footnotetext{
${ }^{1}$ Dr. Mohsen Karimi, Dr. Jose L. Diaz de Tuesta, Prof. Helder T. Gomes, Prof. Alírio E. Rodrigues, Prof. José A. C. Silva mohsen.karimi@fe.up.pt Laboratory of Separation and Reaction Engineering, Laboratory of Catalysis and Materials (LSRE/LCM), Department of Chemical Engineering, Faculty of Engineering, University of Porto, Rua Dr. Roberto Frias, S/N, 4099-002 Porto, Portugal.

${ }^{2}$ Dr. Mohsen Karimi, Dr. Jose L. Diaz de Tuesta, Carmem N. d. P. Gonçalves, Prof. Helder T. Gomes, Prof. José A. C. Silva jsilva@ipb.pt

Centro de Investigação de Montanha (CIMO), Instituto Politécnico de Bragança, Campus de Santa Apolónia, 5300-253 Bragança, Portugal.
} 


\subsection{Objective}

A summary of main objectives of this study is given in Fig. 1. Based on the scopes of the carbon capture and storage (CCS) and the MSW management a novel strategy named integrated management of environment (IME) is proposed. In this way, the obtained compost in the mechanical biological treatment from the MSWs is considered as a low-cost source of adsorbent for $\mathrm{CO}_{2}$ capture, which can be a promising technique for solid waste disposal.

\section{Materials and Methods}

\subsection{Materials and Chemicals}

In this work, the compost was supplied from a municipal solid waste management company (Resíduos do Nordeste, EIM, Portugal), after maturation of the digested side stream resulting from anaerobic digestion of the organic fraction of undifferentiated MSW sorted at the mechanical and biological treatment unit. Sulfuric acid (96-98 wt \%) was obtained from Riedel-deHaën. $\mathrm{CO}_{2}$ and helium were supplied by Air Liquide, with purities of $99.98 \%$ and $99.95 \%$, respectively.

\subsection{Compost Preparation}

The composts were obtained under the controlled aerobic decomposition of MSWs by the operation of microorganisms and small invertebrates. The rate of compost formation was adjusted by temperature, supplied moisture, and percentage of air in the reactor. Among all factors, the $\mathrm{C} / \mathrm{N}$ ratio is the main one to prepare efficiently compost from the MSWs because

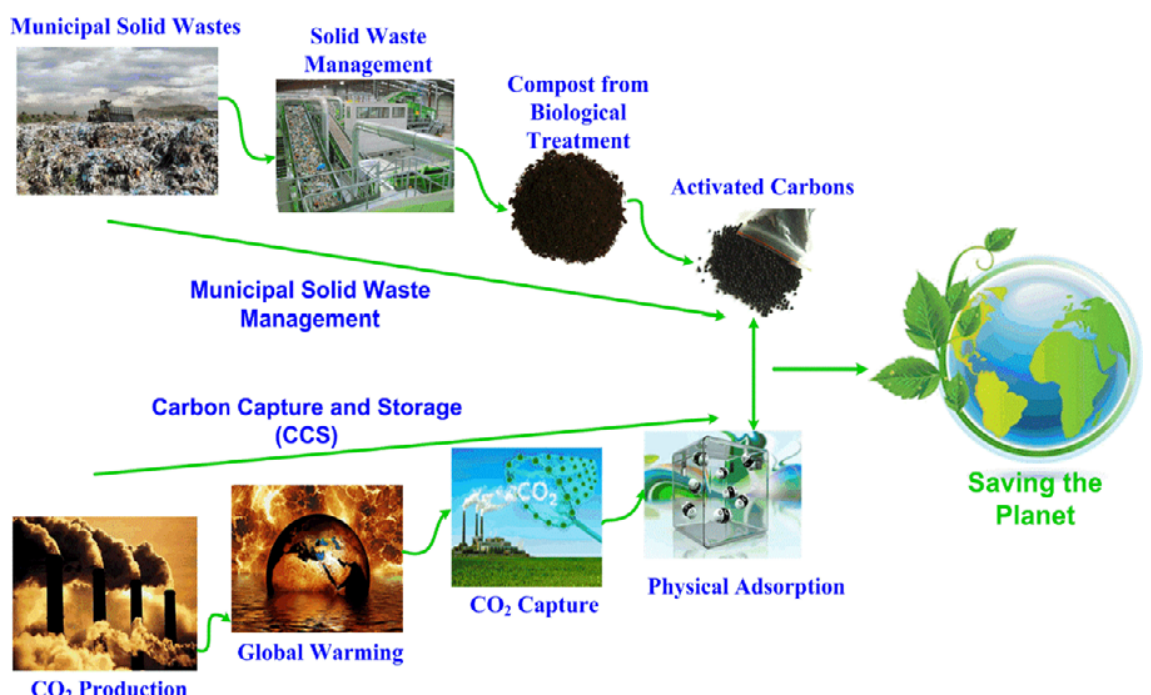

Figure 1. Integrated management of environment (IME) by $\mathrm{CO}_{2}$ capture using materials developed from the municipal solid wastes. carbon supplies the required energy for the microorganisms, while the nitrogen supports the growth of some available proteins.

The temperature is the other operational condition which should be controlled during the decomposition process. The desirable range of temperature is $50-60^{\circ} \mathrm{C}$, the optimum being $60^{\circ} \mathrm{C}$. Finally, the air should be adjusted to supply the required oxygen in the aeration step. More details about this process can be found in [15]. The simple schematic of this process is depicted in Fig. 2. The supplied composts are characterized in Tab. 1.

\subsection{Activation Techniques}

A summary of the activation procedure of different samples is illustrated in Fig. 3. In addition, a detailed description of this procedure is reported in Sect. S1 in the Supporting Information.

\subsection{Characterization of Adsorbents}

The elemental composition was quantified on a Carlo Erba EA 1108 Elemental Analyzer to determine the C, H, N, and S content of each prepared sample. Thermogravimetric analysis (TGA) was performed using a Netzsch STA 409 PC equipment under oxidative atmosphere. For that purpose, the samples were heated under air atmosphere condition from $323 \mathrm{~K}$ to $1273 \mathrm{~K}$ at $10 \mathrm{~K} \mathrm{~min}^{-1}$.

The analysis of $\mathrm{N}_{2}$ adsorption-desorption isotherms at $77 \mathrm{~K}$ was performed with a Quantachrome NOVA 4200e adsorption analyzer to detect the textural properties of the prepared samples. The Brunauer-Emmett-Teller (BET)-specific surface area $\left(S_{\mathrm{BET}}\right)^{1)}$ was calculated by the BET method [16]. The external surface area $\left(S_{\text {ext }}\right)$ and the micropore volume $\left(V_{\text {Mic }}\right)$ were measured by applying the $t$-method [17] and employing the ASTM standard D-6556-01 to calculate the thickness $(t)$. Then, the microporous surface area $\left(S_{\mathrm{Mic}}\right)$ was calculated by subtracting the $S_{\text {ext }}$ from $S_{\text {BET }}$. Also, the approximation $W_{\text {Mic }}=4 V_{\text {Mic }} / S_{\text {Mic }}$ was considered to determine the average pore width $\left(W_{\text {Mic }}\right)$. In addition, the total pore volume $\left(V_{\text {Total }}\right)$ was considered at $p / p^{0}=0.98$.

\subsection{Breakthrough Experiments}

In order to evaluate the uptake capacities of the prepared samples for $\mathrm{CO}_{2}$ capture, breakthrough experiments were performed in a fixed-bed adsorption unit built at our laboratory LSRELCM, which is illustrated in Fig. 4. In order to perform the adsorption experiments, in the first step an adsorption

1) List of symbols at the end of the paper. 


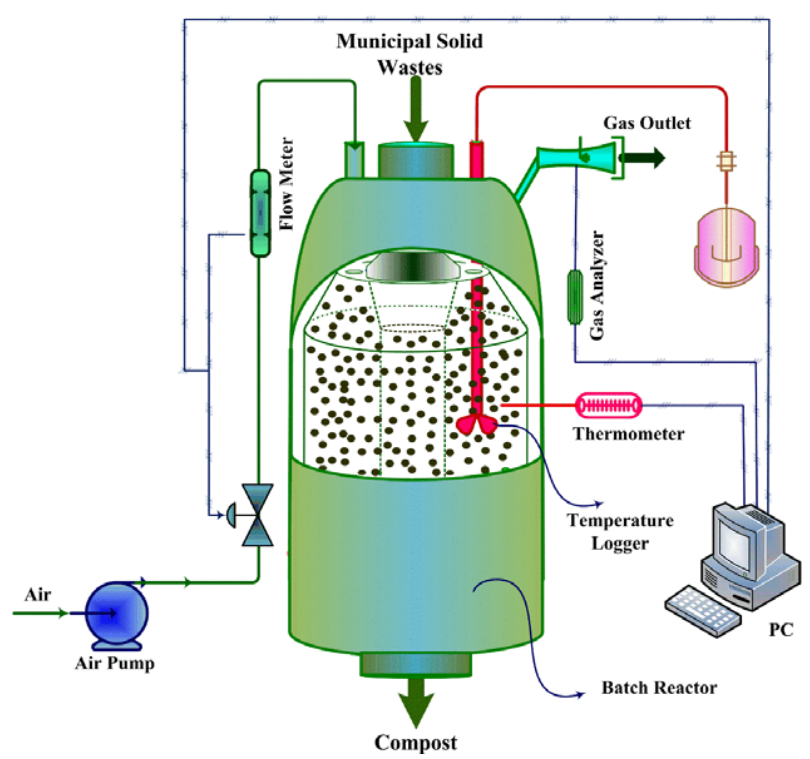

Figure 2. Scheme of the digestive process to obtain biogas and prepare compost.

column is filled with adsorbents. Then, the preparation procedure is accomplished by passing the hot career gas (helium) in the column for $12 \mathrm{~h}$ to remove impurities and moisture. After that, the adsorption process is initiated by introducing the adsorbate gas and carrier gas to the system. In this step, the system is analyzed continuously by measuring the mass flow rate at the output of the column with a thermal conductivity detector (TCD). Finally, after reaching the saturation conditions, the regeneration process (desorption) is started by switching the gas flow rate to the career gas to desorb the adsorbed $\mathrm{CO}_{2}$ on the bed. More details about this unit can be found in our previous study [18].

After gathering the TCD results, a mass balance was considered on the adsorption bed to determine the uptake capacity of sorbents as follows:
Table 1. Characterization of compost material derived from municipal solid waste based on dry conditions.

\begin{tabular}{|c|c|}
\hline Parameter & Value \\
\hline Moisture [\%] & 29.6 \\
\hline Organic matter [\%] & 48.8 \\
\hline $\mathrm{C}[\%]$ & 27.1 \\
\hline $\mathrm{N}[\%]$ & 1.3 \\
\hline $\mathrm{P}_{2} \mathrm{O}_{5}[\%]$ & 1.1 \\
\hline $\mathrm{K}_{2} \mathrm{O}[\%]$ & 1.4 \\
\hline $\mathrm{Ca}[\%]$ & 4.9 \\
\hline $\mathrm{Mg}[\%]$ & 0.8 \\
\hline$S[\%]$ & 0.6 \\
\hline $\mathrm{B}[\%]$ & 0.0043 \\
\hline $\mathrm{Cd}[\%]$ & $9 \times 10^{-5}$ \\
\hline $\mathrm{Cr}[\%]$ & 0.013 \\
\hline $\mathrm{Cu}[\%]$ & 0.021 \\
\hline $\mathrm{Hg}[\%]$ & $4 \times 10^{-5}$ \\
\hline $\mathrm{Ni}[\%]$ & 0.0049 \\
\hline $\mathrm{Pb}[\%]$ & 0.011 \\
\hline $\mathrm{Zn}[\%]$ & 0.045 \\
\hline Anthropogenic inert [\%] & 0.7 \\
\hline Escherichia coli $\left[\mathrm{g}^{-1}\right]$ & 460 \\
\hline Density $\left[\mathrm{kg} \mathrm{dm}^{-3}\right]$ & 0.45 \\
\hline Electric conductivity $\left[\mathrm{mS} \mathrm{cm}^{-1}\right]$ & 2.5 \\
\hline $\mathrm{pH}[-]$ & 8.0 \\
\hline
\end{tabular}

$Q_{\mathrm{CO}_{2}}=\frac{1}{m_{\text {adsorbent }}}\left[\int_{0}^{\mathrm{t}_{\mathrm{s}}}\left(F_{\mathrm{CO}_{2, \text { in }}}-F_{\mathrm{CO}_{2, \text { out }}}\right) \mathrm{d} t-\frac{y_{\mathrm{CO}_{2}, \text { feed }} P_{\mathrm{b}} \varepsilon_{\mathrm{T}} V_{\mathrm{b}}}{Z R_{\mathrm{g}} T_{\mathrm{b}}}-\frac{y_{\mathrm{CO}_{2}, \text { feed }} P_{\mathrm{b}} V_{\mathrm{d}}}{Z R_{\mathrm{g}} T_{\mathrm{b}}}\right]$

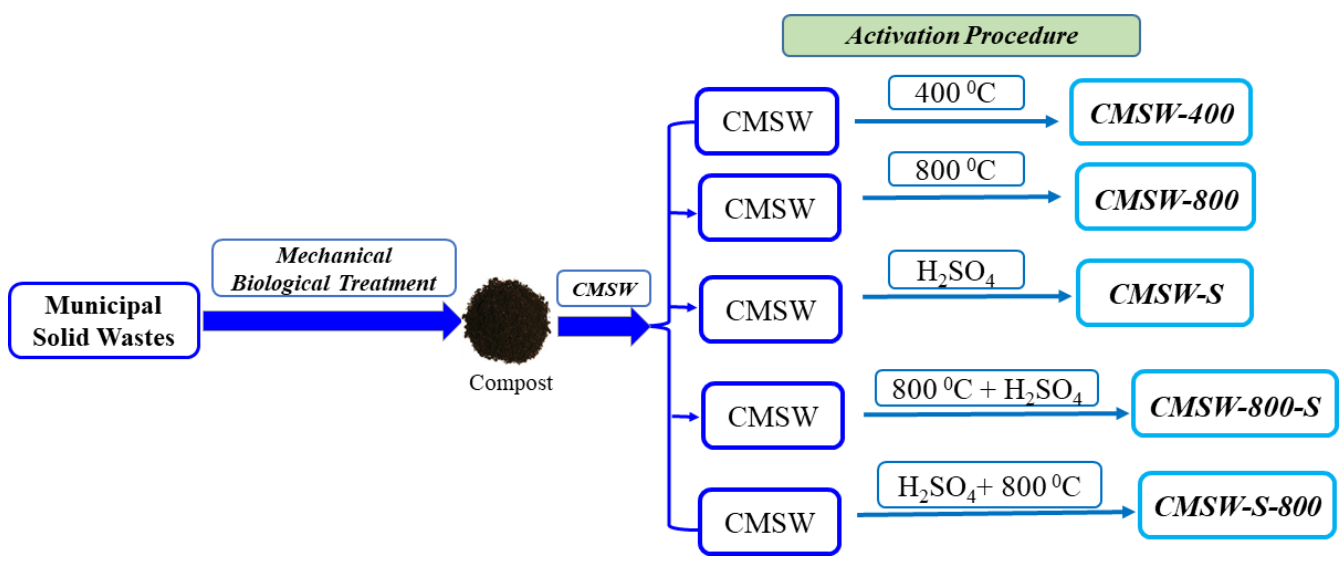

Figure 3. Scheme of activation procedure of the different proposed samples. 


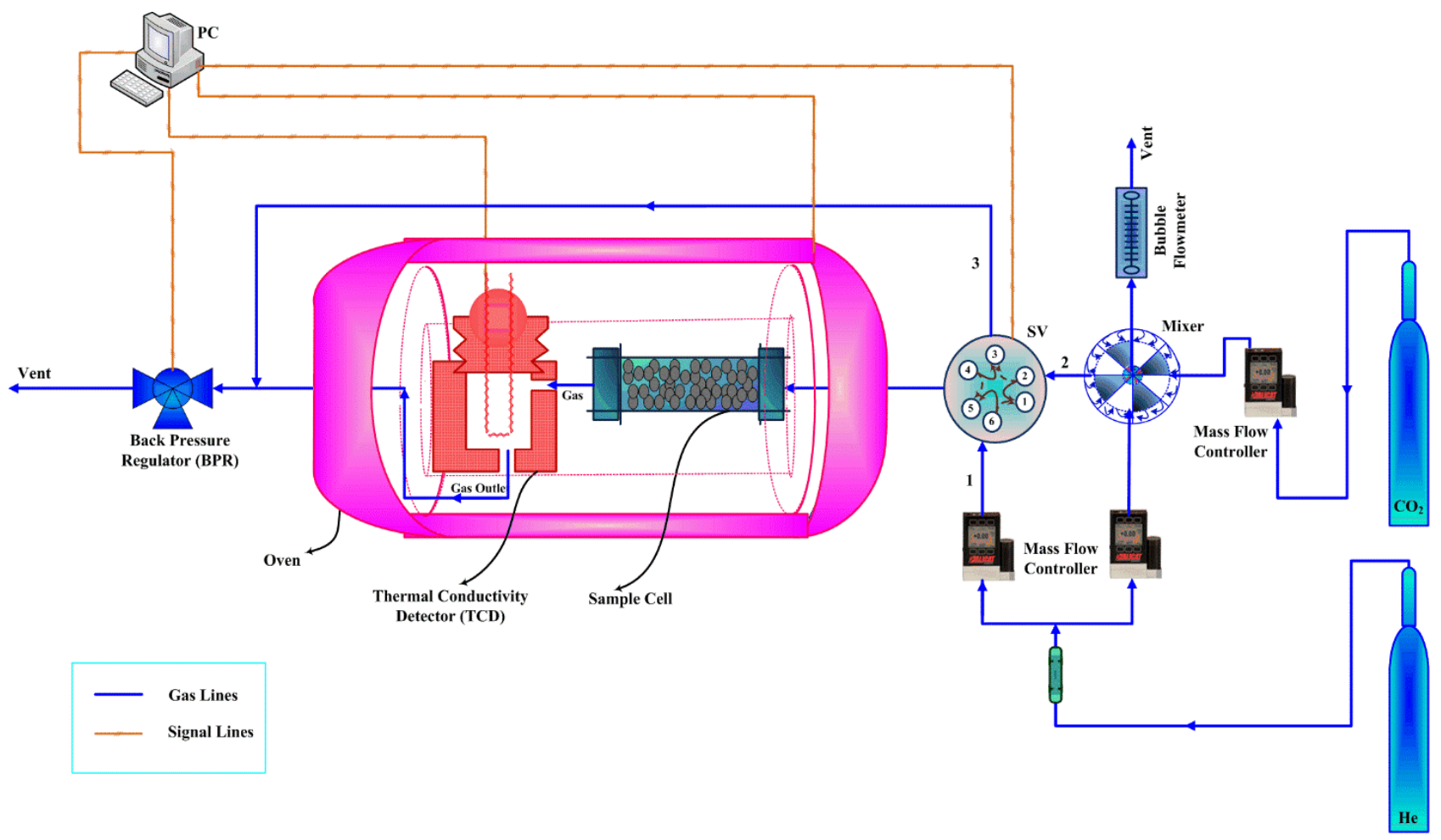

Figure 4. Experimental setup used to measure the adsorption equilibrium of prepared samples.

Here, $t_{\mathrm{s}}$ is the saturation time of the bed and $\varepsilon_{\mathrm{T}}$ is the total porosity of the bed, which is determined by Eq. (2) [19]:

$\varepsilon_{\mathrm{T}}=\varepsilon_{\mathrm{b}}+\left(1-\varepsilon_{\mathrm{b}}\right) \varepsilon_{\mathrm{p}}$
Where $\varepsilon_{\mathrm{p}}$ is the particle porosity and $\varepsilon_{\mathrm{b}}$ is the packed bed porosity. More details about the breakthrough unit and operational conditions are presented in Tab. 2 .

Table 2. Specific properties and operating conditions of breakthrough apparatus.

\begin{tabular}{|c|c|c|c|c|c|}
\hline & CMSW-400 & CMSW-800 & CMSW-S & CMSW-800-S & CMSW-S-800 \\
\hline \multicolumn{6}{|l|}{ Bed characteristics } \\
\hline Bed inner diameter $[\mathrm{cm}]$ & 0.46 & & & & \\
\hline Bed length [cm] & 10 & & & & \\
\hline Wall thickness [cm] & 0.089 & & & & \\
\hline \multicolumn{6}{|l|}{ Total parameters of experiments } \\
\hline Mass of sample $[\mathrm{g}]$ & $\sim 0.6$ & $\sim 0.6$ & $\sim 0.6$ & $\sim 0.6$ & $\sim 0.6$ \\
\hline Ambient pressure [bar] & 1 & 1 & 1 & 1 & 1 \\
\hline Ambient temperature $[\mathrm{K}]$ & 293.75 & 295.55 & 294.85 & 295.25 & 293.05 \\
\hline $\mathrm{CO}_{2}$ flow rate $\left[\mathrm{mL} \mathrm{min}^{-1}\right]$ & $\sim 10$ & $\sim 10$ & $\sim 10$ & $\sim 10$ & $\sim 10$ \\
\hline Helium flow rate $\left[\mathrm{mL} \mathrm{min}^{-1}\right]$ & $\sim 9$ & $\sim 9$ & $\sim 9$ & $\sim 9$ & $\sim 9$ \\
\hline Particle sizes $[\mu \mathrm{m}]$ & $53-106$ & $53-106$ & $53-106$ & $53-106$ & $53-106$ \\
\hline \multicolumn{6}{|l|}{ Operating conditions } \\
\hline Temperature $\left[{ }^{\circ} \mathrm{C}\right]$ & 40 & 40 & 40 & 40 & 40 \\
\hline Total pressure [bar] & $1-5$ & $1-5$ & $1-5$ & $1-5$ & $1-5$ \\
\hline
\end{tabular}




\section{Modeling and Simulation}

\subsection{Breakthrough Modeling}

In order to scale up the adsorption system, the analysis of the adsorption equilibrium data is required to estimate the adsorption capacities of the adsorbents. In this study, the Langmuir model, as the most popular model to describe monolayer adsorption processes, was applied to evaluate the obtained experimental data $[20,21]$. In this model, the $R^{2}$ is considered to determine the accuracy of the fitted model to the experimental values. The Langmuir model is defined as:

$Q_{\mathrm{e}}=\frac{Q_{\mathrm{m}} K_{\mathrm{L}} P_{\mathrm{CO}_{2}}}{1+K_{\mathrm{L}} P_{\mathrm{CO}_{2}}}$

Here, $K_{\mathrm{L}}$ as the Langmuir adsorption constant, determines the strength of created bonds between the adsorbate molecules and adsorbents, which can be described by:

$$
\begin{aligned}
K_{\mathrm{L}} & =\frac{\alpha \exp \left(\Delta H / R_{\mathrm{g}} T\right)}{k_{\mathrm{d} \infty} \sqrt{2 \pi M R_{\mathrm{g}} T}}=K_{\infty} \exp \left(\Delta H / R_{\mathrm{g}} T\right) \\
K_{\infty} & =\frac{\alpha}{k_{\mathrm{d} \infty} \sqrt{2 \pi M R_{\mathrm{g}} T}}
\end{aligned}
$$

where $\Delta H$ is the heat of adsorption, $\alpha$ denotes the sticking coefficient, $T$ is the temperature, and $M$ is the molecular weight. In addition, $R^{2}$ is calculated by:

$R^{2}=1-\frac{\sum_{\mathrm{i}=1}^{\mathrm{n}}\left(y_{\mathrm{i}}-f_{\mathrm{i}}\right)^{2}}{\sum_{\mathrm{i}=1}^{\mathrm{n}}\left(y_{\mathrm{i}}-\bar{y}\right)^{2}}$

$\bar{y}=\frac{1}{n} \sum_{\mathrm{i}=1}^{\mathrm{n}} y_{\mathrm{i}}$

where $y_{\mathrm{i}}$ and $f_{\mathrm{i}}$ are the experimental and predicted vales, respectively.

\subsection{Response Surface Methodology}

Response surface methodology (RSM) is a combination of statistical and mathematical methods which is employed to design experiments, develop models, determine the parameter interactions, and also to find the optimal values of independent variables [22]. Among the different methods of RSM, the central composite design (CCD) is the most popular one $[9,22]$. In this way, the obtained experimental values for the mathematicalstatistical treatment are fitted to a quadratic equation as follows:

$Y=\beta_{0}+\sum_{\mathrm{i}=1}^{\mathrm{n}} \beta_{\mathrm{i}} x_{\mathrm{i}}+\sum_{\mathrm{i}=1}^{\mathrm{n}} \beta_{\mathrm{ii}} x_{\mathrm{i}}^{2}+\sum_{\mathrm{i}=1}^{\mathrm{n}} \sum_{\mathrm{j}=\mathrm{i}+1}^{\mathrm{n}} \beta_{\mathrm{ij}} x_{\mathrm{i}} x_{\mathrm{j}}+\varepsilon$

where $Y$ is the response value, $x_{\mathrm{i}}$ and $x_{\mathrm{j}}$ indicate the independent variables, which are defined in the range of [0-1] as coded values of model factors, $\beta_{\mathrm{i}}$ and $\beta_{\mathrm{j}}$ illustrate the linear coefficients of independent variables, while $\beta_{\mathrm{ii}}$ or $\beta_{\mathrm{jj}}$ display the quadratic coefficients of the model, and $\beta_{0}$ is the intercept coefficient. In addition, the interaction effects between the independent variables is defined by $\beta_{\mathrm{ij}}$.

In this equation, the residual error is calculated by $\varepsilon$. Then, by employing the least square method and multiple regression analysis, the mentioned coefficients are computed contributing to a general correlation. In this way, the regression analysis of variance (ANOVA) of the designed model is performed by the statistical evaluation of results to get a significant model for the adsorption process. Then, the model lack-of-fit, which determines the variations of the data around the fitted model, should be considered, and if the model does not fit the data very well, the lack-of-fit will be significant and contributes to an undesirable model [23].

Also, $p$ values indicate the effects of the considered terms of the model on the responses. The accuracy of the obtained model is evaluated by using the regression coefficients $\left(R^{2}\right.$ and adjusted $R^{2}$ ) and the standard deviation (Eqs. (9)-(11)), to achieve the best response.

$R^{2}=1-\frac{\sum_{\mathrm{i}=1}^{\mathrm{n}}\left(y_{\mathrm{i}}-\hat{y}_{\mathrm{i}}\right)^{2}}{\sum_{\mathrm{i}=1}^{\mathrm{n}}\left(y_{\mathrm{i}}-\bar{y}\right)^{2}}$

$\operatorname{Adj}-R^{2}=1-\frac{\left(1-R^{2}\right)(n-1)}{(n-P-1)}$

Std. Dev. $=\sqrt{\frac{\sum_{\mathrm{i}=1}^{\mathrm{n}}\left(y_{\mathrm{i}}-\hat{y}_{\mathrm{i}}\right)^{2}}{n-P}}$

Here, $y_{\mathrm{i}}, \hat{y}_{\mathrm{i}}$, and $\bar{y}$ denote the experimental data, the predicted value by the model, and the average of experimental data, respectively. In addition, $n$ and $P$ are the numbers of experiments and predictors, respectively [24].

\section{Results and Discussion}

\subsection{Characterization of Adsorbents}

The elemental analysis related to the $\mathrm{C}, \mathrm{H}, \mathrm{S}$, and $\mathrm{N}$ content of the prepared samples is summarized in Tab.3. As can be observed, the carbon content is less than $25 \%$ for all prepared samples, and the sum of $\mathrm{C}, \mathrm{H}, \mathrm{S}$, and $\mathrm{N}$ does not reach the value of $30 \%$ for each one, obtaining a remaining from the elemental analysis higher than $70 \%$ that commonly is ascribed to the ashes and oxygen content. Also, the preparation of the samples shows a burn-off (weight loss) in consonance with the disappearance of volatile compounds and inorganic substances as consequence of the calcination and acid treatments, respectively, as reported in Tab. 4. More characterizations of samples are discussed in detail in Sect. S2 in the Supporting Information. 
Table 3. Elemental analysis of the prepared samples.

\begin{tabular}{lllllll}
\hline Sample & $\mathrm{C}[\%]$ & $\mathrm{H}[\%]$ & $\mathrm{S}[\%]$ & $\mathrm{N}[\%]$ & Remaining $^{\text {a) }}[\%]$ & Ashes $^{\text {b) }}[\%]$ \\
\hline CMSW-400 & 15.6 & 1.0 & 0.3 & 0.9 & 82.2 & 64.9 \\
CMSW-800 & 17.5 & 0.4 & 0.4 & 0.0 & 81.6 & 80.6 \\
CMSW-S & 20.1 & 2.3 & 0.6 & 1.7 & 70.4 & 34.3 \\
CMSW-S-800 & 20.5 & 1.9 & 0.4 & 1.4 & 75.8 & 65.9 \\
CMSW-800-S & 18.6 & 0.5 & 8.1 & 0.0 & 72.7 & 72.4 \\
\hline
\end{tabular}

${ }^{a}$ Remaining was obtained from the subtraction of C, H, S, N, content from $100 \%$; ${ }^{\text {b) ashes }}$ values correspond with the weight of the samples at the end of the TGA in oxidizing atmosphere.

Table 4. Burn-off during the preparation of the prepared samples and textural properties of materials determined from BET and $t$-plot methods.

\begin{tabular}{llclcccc}
\hline Sample & $\begin{array}{l}\text { Burn-off } \\
{[\%]}\end{array}$ & $\begin{array}{l}S_{\mathrm{BET}} \\
{\left[\mathrm{m}^{2} \mathrm{~g}^{-1}\right]}\end{array}$ & $\begin{array}{l}S_{\text {ext }} \\
{\left[\mathrm{m}^{2} \mathrm{~g}^{-1}\right]}\end{array}$ & $\begin{array}{l}S_{\text {Mic }} \\
{\left[\mathrm{m}^{2} \mathrm{~g}^{-1}\right]}\end{array}$ & $\begin{array}{l}V_{\text {Mic }} \\
{\left[\mathrm{mm}^{3} \mathrm{~g}^{-1}\right]}\end{array}$ & $\begin{array}{l}V_{\text {Mic }} / V_{\text {Total }} \\
{[\%]}\end{array}$ & $\begin{array}{l}W_{\text {Mic }} \\
{[\mathrm{nm}]}\end{array}$ \\
\hline CMSW-400 & 23.9 & 22 & 22 & 0 & 0 & 0.0 & 0.0 \\
CMSW-800 & 39.9 & 77 & 52 & 25 & 12 & 14.0 & 1.9 \\
CMSW-S & 59.6 & 11 & 11 & 0 & 0 & 0.0 & - \\
CMSW-S-800 & 76.3 & 279 & 56 & 223 & 92 & 53.4 & 1.6 \\
CMSW-800-S & 58.7 & 91 & 60 & 31 & 14 & 13.6 & 1.8 \\
\hline
\end{tabular}

\subsection{Breakthrough Adsorption Evaluation}

The breakthrough adsorption runs on the synthesized samples were performed at $40^{\circ} \mathrm{C}$ and different pressures in the range of 1-5 bar. In this way, the inlet flow rate containing a specified percentage of $\mathrm{CO}_{2}$ was fed to the fixed-bed column and the gas adsorption was started at the beginning of the column, i.e., the main region of the mass transfer zone (MTZ), on the fresh adsorbents until getting a saturation condition. Concerning the breakthrough curves, it should be considered that the ideal MTZ has no axial dispersion and no mass transfer resistance, which contributes to a short width, also a vertical line from 0 to 1.0. These behaviors can be observed in Figs. 5a-e. As shown, by increasing the total pressure from 1 to 5 bar, the MTZs are increased, which it can be interpreted by the reduction of the mass transfer rate because of the axial dispersion [25]. It is a worth mentioning that a shorter MTZ is favorable for the gas adsorption in the view of reduction of energy costs for the regeneration process [25].

The results of integration on the breakthrough curves by employing Eq. (1) contribute to the adsorption capacities of the samples [26]. The isotherm results of the prepared samples in this work are illustrated in Fig. 6a. As can be expected, the uptake capacities of all samples are increased by enhancing the pres-
Table 5. Langmuir parameters of $\mathrm{CO}_{2}$ adsorption on prepared CMSW samples at $40^{\circ} \mathrm{C}$.

\begin{tabular}{llllll}
\hline Langmuir coefficients & CMSW-400 & CMSW-800 & CMSW-S & CMSW-800-S & CMSW-S-800 \\
\hline$Q_{\mathrm{m}}\left[\mathrm{mmol} \mathrm{g}^{-1}\right]$ & 2.09 & 2.31 & 2.26 & 2.67 & 3.29 \\
$K_{\mathrm{L}}\left[\mathrm{bar}^{-1}\right]$ & 0.34 & 0.26 & 0.47 & 1.01 & 0.98 \\
$R^{2}$ & 0.97 & 0.98 & 0.98 & 0.94 & 0.97 \\
\hline
\end{tabular}

sure, which can be explained by Le Chatelier's principle, which considers the $P_{\mathrm{CO} 2}$ increment as a driving force for adsorption systems.

As previously mentioned, in this study the Langmuir model was applied to analyze and predict the isotherm results. In Fig. 6a the solid curves represent the results of the Langmuir model, and the marker points express the obtained experimental values. There is a good agreement between the experimental and modeling results, which demonstrates that this model is able to satisfactorily predict the behavior of the adsorption process. This is also confirmed by the Langmuir fitting results $\left(R^{2}\right)$, which are reported in Tab. 5.

The uptake capacities of the prepared samples for $\mathrm{CO}_{2}$ capture are compared in Fig. 6b. CMSWS-800, which was subsequently treated chemically with sulfuric acid and then physically at $800^{\circ} \mathrm{C}$, has the highest uptake capacity, and CMSW-400 that was thermally activated at $400{ }^{\circ} \mathrm{C}$, has the lowest adsorption capacity. To interpret the behaviors of these solid adsorbents, several factors should be taken into account. As can be expected, the chemical activation has a better effect than physical activation on the carbon-based materials for carbon capture [27]. Thus, CMSW-400 and CMSW-800 have lower adsorption capacities than other ones, and obviously the CMSW-800 sample due to the treatment at the higher temperature exhibits a better performance than the CMSW-400 sample.

On the other hand, based on the textural properties of the prepared samples (Tab.4), CMSW-S-800 has the largest surface area compared to the other ones. Most of the adsorption occurs in these pores. CMSW-800-S is the other sample with high surface area, which is the next ideal adsorbent in this study. In addition, the higher uptake capacity of CMSW-S-800 can be also interpreted based on the consequence of the thermal treatment of this sample, which has been chemically activated in the previous step. Some of the functional groups, which are able to block the available pores, were removed and some new adsorption sites emerged. Thus, this sample shows a better performance for $\mathrm{CO}_{2}$ adsorption. To have a better knowledge about the adsorption capacity of the best synthesized adsorbent (CMSW-S-800), a comparison with some of the recently studied sorbents for $\mathrm{CO}_{2}$ capture is presented in Tab. 6. 
a)
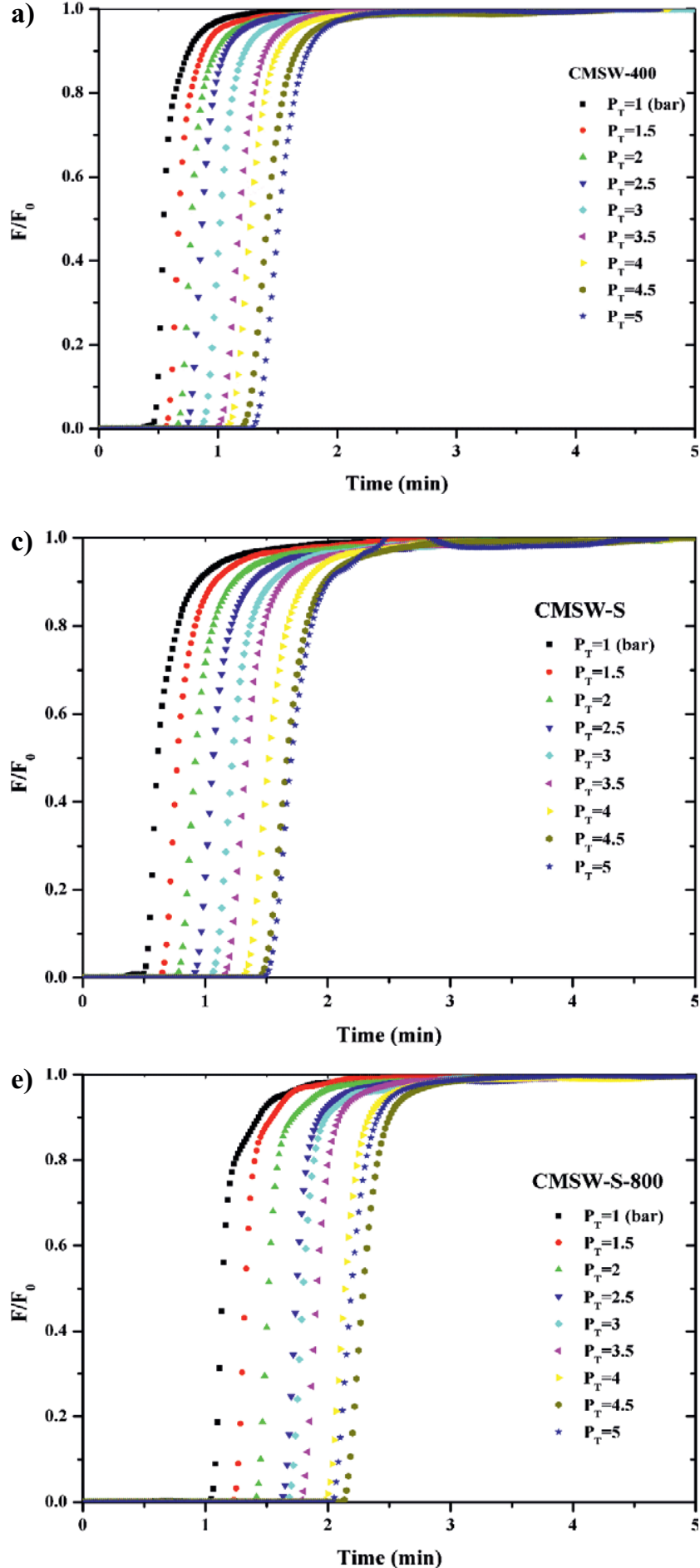
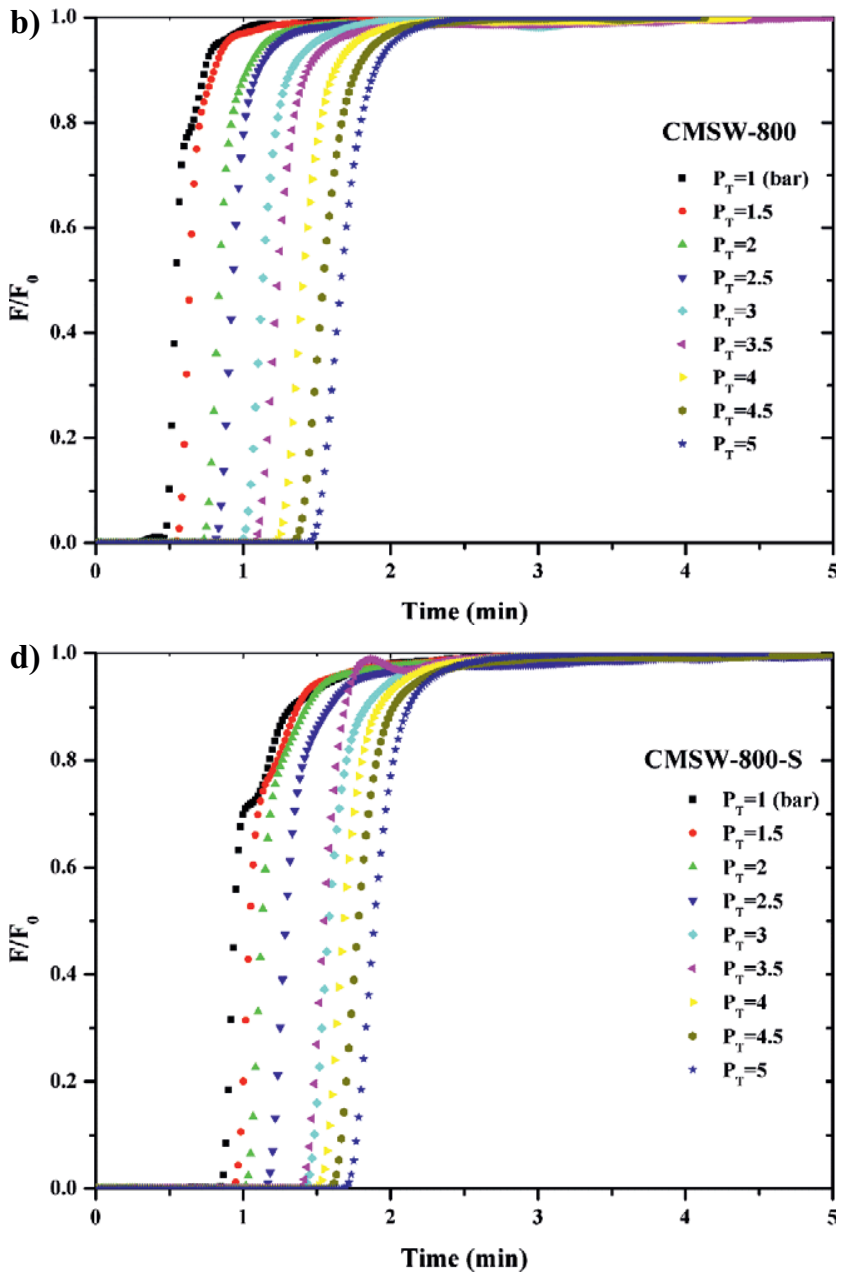

Figure 5. Breakthrough curves of adsorption measurements of $\mathrm{CO}_{2}$ at $40^{\circ} \mathrm{C}$ of (a) CMSW- 400 , (b) CMSW-800, (c) CMSW-S, (d) CMSW-800-S, (e) CMSW-S-800.

\subsection{Central Composite Design Analysis}

The adsorption of $\mathrm{CO}_{2}$ on the newly developed adsorbents CMSW-S-800 and CMSW-800-S was assessed in the temperature range of $40-100^{\circ} \mathrm{C}$ by applying the $\mathrm{CCD}$ as a design mod- el to the experimental runs [31-33]. The experimental values of input variables and their coded values, and also the response surfaces for CMSW-800-S and CMSW-S-800 samples are listed in Tab. 7. 


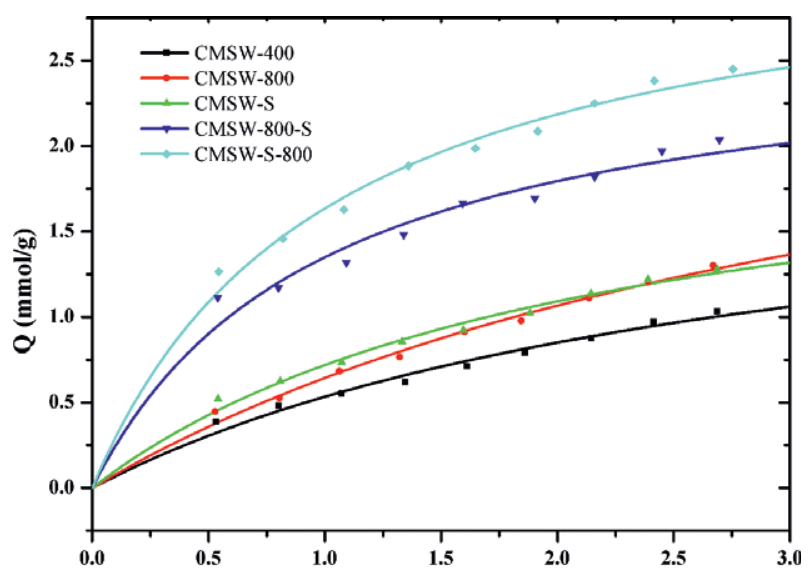

a)

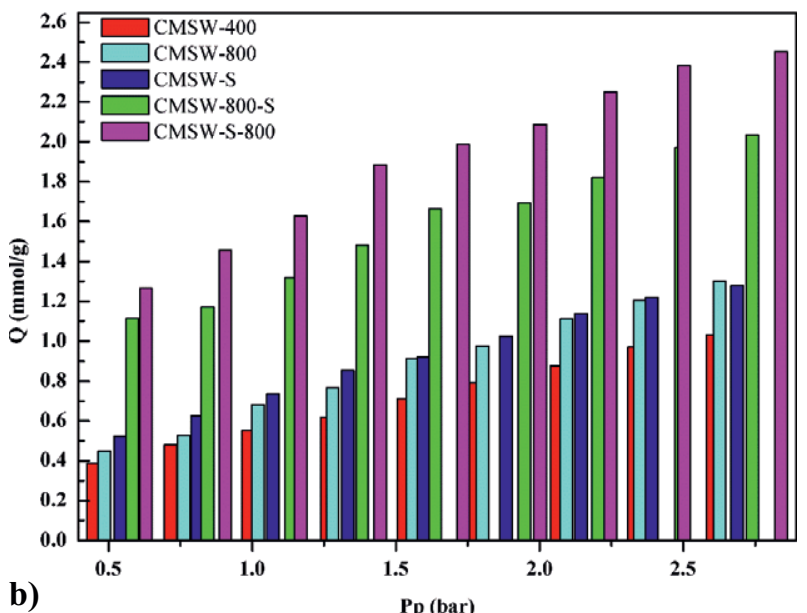

Figure 6. (a) Experimental equilibrium data (symbols) and fitted Langmuir isotherm (lines) for $\mathrm{CO}_{2}$ adsorption at $40^{\circ} \mathrm{C}$; (b) comparison between $\mathrm{CO}_{2}$ uptake capacity $\left(\mathrm{mmol} \mathrm{g}^{-1}\right)$ of investigated adsorbents.
The obtained experimental values were fitted with quadratic models to develop the general correlations for the uptake capacity and the breakthrough time of the specified samples. After that, the statistical analysis of models was carried out by employing the multiple regression analysis of ANOVA and considering the fitness of the models. In this regard, the significance of model and lack-of-fit, the coded coefficients, standard deviation, $R^{2}$, adjusted $R^{2}\left(A d j-R^{2}\right)$, and $p$ values should be considered and analyzed. Then, the final models were developed after eliminating the insignificant interactions and parameters in the adsorption system. The ANOVA results of the employed polynomial models for the mentioned samples are summarized in Tabs. 8 and 9, respectively.

In addition, based on the regression analysis of ANOVA, the obtained response variables for the CMSW-800-S sample with non-coded values of $T$ and $P$ are as follows:

$$
\begin{aligned}
&\left(Q_{\mathrm{CO}_{2}}\right)_{\mathrm{CMSW}-800 \mathrm{~S}}= 1.73+0.796 P-0.03 T \\
&-(0.0035 P T)-0.045 P^{2} \\
&+0.00017 T^{2} \\
&\left(t_{\mathrm{b}}\right)_{\mathrm{CMSW}-800 \mathrm{~S}}=2.92+0.398 P-0.02 T-(0.0005 P T) \\
&+ \\
&+0.049 P^{2}+0.00008 T^{2}
\end{aligned}
$$

The uptake capacity and breakthrough time of the CMSWS-800 sample are defined by the following equations:

$$
\begin{aligned}
\left(Q_{\mathrm{CO}_{2}}\right)_{\mathrm{CMSW}-\mathrm{S} 800}= & 1.59+1.426 P-0.025 T \\
& -(0.001 P T)-0.247 P^{2} \\
& +0.0001 T^{2}
\end{aligned}
$$

\begin{tabular}{|c|c|c|c|c|c|c|c|c|}
\hline Adsorbent & Type of activation & $\begin{array}{l}m_{\text {adsorbant }} \\
{[\mathrm{g}]}\end{array}$ & Porosity & $\begin{array}{l}P_{\mathrm{CO} 2} \\
{[\mathrm{bar}]}\end{array}$ & $\begin{array}{l}T \\
{[\mathrm{~K}]}\end{array}$ & Adsorption technique & $\begin{array}{l}Q \\
{\left[\mathrm{mmolg}^{-1}\right]}\end{array}$ & Ref. \\
\hline \multirow{4}{*}{$\begin{array}{l}\text { AC derived from } \\
\text { coconut shell chars }\end{array}$} & Heat treatment at $250^{\circ} \mathrm{C}$ & 0.2 & Microporous & 2.5 & 273 & \multirow{4}{*}{$\begin{array}{l}\text { Intelligent gravimetric } \\
\text { analyzer (IGA) }\end{array}$} & 1.5 & \multirow[t]{4}{*}{28} \\
\hline & Heat treatment at $350^{\circ} \mathrm{C}$ & 0.2 & & 2.5 & 273 & & 2.15 & \\
\hline & Heat treatment at $450^{\circ} \mathrm{C}$ & 0.2 & & 2.5 & 273 & & 2.7 & \\
\hline & Heat treatment at $450^{\circ} \mathrm{C}$ & 0.2 & & 2.5 & 273 & & 3.6 & \\
\hline $\begin{array}{l}\text { AC derived from } \\
\text { pine sawdust }\end{array}$ & $\mathrm{CO}_{2}$ & 4 & Microporous & 2.5 & 323 & $\begin{array}{l}\text { Magnetic suspension } \\
\text { balance }\end{array}$ & 2.8 & [29] \\
\hline \multirow[t]{3}{*}{ MOF Fe(BTC) } & \multirow{3}{*}{$\begin{array}{l}\text { Elevated by mixed- matrix } \\
\text { membranes }\end{array}$} & \multirow[t]{3}{*}{-} & \multirow[t]{3}{*}{ Mesoporous } & 2.5 & 303 & \multirow{3}{*}{$\begin{array}{l}\text { Thermogravimetric } \\
\text { analysis (TGA) }\end{array}$} & 1.5 & \multirow[t]{3}{*}[30]{} \\
\hline & & & & 2.5 & 323 & & 1.3 & \\
\hline & & & & 2.5 & 353 & & 0.8 & \\
\hline $\begin{array}{l}\text { AC (Norit } \\
\text { R2030CO2) }\end{array}$ & Steam activation & 3.22 & Microporous & 2 & 418 & Breakthrough technique & 2.5 & [31] \\
\hline
\end{tabular}

$$
\begin{aligned}
\left(t_{\mathrm{b}}\right)_{\mathrm{CMSW}-\mathrm{S} 800}= & 3.069+1.136 P-0.02 T-(0.0019 P T) \\
& -0.163 P^{2}+0.00007 T^{2}
\end{aligned}
$$

Table 6. Comparison between the adsorption capacities of recent proposed adsorbents for $\mathrm{CO}_{2}$ capture. 
Table 6. Continued

\begin{tabular}{|c|c|c|c|c|c|c|c|c|}
\hline Adsorbent & Type of activation & $\begin{array}{l}m_{\text {adsorbant }} \\
{[\mathrm{g}]}\end{array}$ & Porosity & $\begin{array}{l}P_{\mathrm{CO} 2} \\
{[\text { bar }]}\end{array}$ & $\begin{array}{l}T \\
{[\mathrm{~K}]}\end{array}$ & Adsorption technique & $\begin{array}{l}Q \\
{\left[\mathrm{mmolg}^{-1}\right]}\end{array}$ & Ref. \\
\hline Zeolite H-BETA-25 & $\mathrm{n} / \mathrm{a}$ & 0.65 & \multirow{3}{*}{$\begin{array}{l}\text { Micro-/meso- } \\
\text { porous }\end{array}$} & 2.5 & 313 & \multirow[t]{3}{*}{ Breakthrough technique } & 1.75 & \multirow[t]{3}{*}[32]{} \\
\hline Zeolite H-BETA-150 & & 0.65 & & 2.5 & 313 & & 1.67 & \\
\hline Zeolite Na-BETA-25 & & 0.65 & & 2.5 & 313 & & 2.21 & \\
\hline \multirow{2}{*}{$\begin{array}{l}\text { AC derived from } \\
\text { pine cone }\end{array}$} & $\mathrm{H}_{3} \mathrm{PO}_{4}$ & - & Microporous & 2.5 & 308 & \multirow[t]{2}{*}{ Volumetric technique } & 2.8 & \multirow[t]{2}{*}[33]{} \\
\hline & & & & 2.5 & 318 & & 2.1 & \\
\hline \multirow{2}{*}{$\begin{array}{l}\text { AC derived from } \\
\text { cherry stones }\end{array}$} & $\mathrm{CO}_{2}$ & 4.08 & Microporous & 2.5 & 323 & \multirow{2}{*}{$\begin{array}{l}\text { Magnetic suspension } \\
\text { balance }\end{array}$} & 2.85 & \multirow[t]{2}{*}[34]{} \\
\hline & Steam & 4.8 & & 2.5 & 323 & & 2.5 & \\
\hline AHEP (algae) & $\mathrm{KOH}$ & 0.7 & $\begin{array}{l}\text { Micro-/meso- } \\
\text { porous }\end{array}$ & 1 & 323 & Breakthrough technique & 0.413 & {$[35]$} \\
\hline AAM-silica & $\mathrm{HCL}$ & 1 & $\begin{array}{l}\text { Micro-/meso- } \\
\text { porous }\end{array}$ & 1 & 318 & Breakthrough technique & 0.78 & {$[36]$} \\
\hline CMSW-800-S & $\begin{array}{l}\text { Heat treatment at } 800^{\circ} \mathrm{C} \text { and } \\
\mathrm{H}_{2} \mathrm{SO}_{4}\end{array}$ & 0.6 & Mesoporous & 2.5 & 313 & Breakthrough technique & 2.15 & $\begin{array}{l}\text { This } \\
\text { Study }\end{array}$ \\
\hline CMSW-S-800 & $\begin{array}{l}\mathrm{H}_{2} \mathrm{SO}_{4} \text { and heat treatment at } \\
800^{\circ} \mathrm{C}\end{array}$ & 0.6 & Mesoporous & 2.5 & 313 & Breakthrough technique & 2.75 & $\begin{array}{l}\text { This } \\
\text { Study }\end{array}$ \\
\hline
\end{tabular}

Table 7. Independent variables and response values for the considered CCD models of CMSW-800-S and CMSW-S-800 adsorbents; Total flow rate: $20 \mathrm{~mL} \mathrm{~min}^{-1}$; mass of adsorbent: $\sim 0.5 \mathrm{~g}$; ambient temperature: $25^{\circ} \mathrm{C}$; ambient pressure: 1 bar; helium flow rate: $\sim 8 \mathrm{~mL} \mathrm{~min}^{-1}$.

\begin{tabular}{|c|c|c|c|c|c|c|c|}
\hline \multirow[t]{2}{*}{ Run } & \multicolumn{2}{|c|}{ Independent variables } & \multirow{2}{*}{$\begin{array}{l}P_{\mathrm{CO} 2} \\
-[\mathrm{bar}]\end{array}$} & \multicolumn{2}{|l|}{ CMSW-800-S } & \multicolumn{2}{|l|}{ CMSW-S-800 } \\
\hline & $T\left[{ }^{\circ} \mathrm{C}\right]$ & $P_{\mathrm{CO} 2}[\mathrm{bar}]$ & & $Q\left[\mathrm{mmol} \mathrm{g}^{-1}\right]$ & $t_{\mathrm{b}}[\min ]$ & $Q\left[\mathrm{mmol} \mathrm{g}^{-1}\right]$ & $t_{\mathrm{b}}[\mathrm{min}]$ \\
\hline 1 & $40(-1)$ & $0.5(-1)$ & 1 & 1.05 & 2.45 & 1.45 & 2.82 \\
\hline 2 & $40(-1)$ & $1.5(0)$ & 3 & 1.75 & 2.95 & 2.15 & 3.65 \\
\hline 3 & $40(-1)$ & $2.5(+1)$ & 5 & 2.15 & 3.46 & 2.75 & 3.95 \\
\hline 4 & $70(0)$ & $0.5(-1)$ & 1 & 0.79 & 2.05 & 0.95 & 2.45 \\
\hline 5 & $70(0)$ & $1.5(0)$ & 3 & 1.15 & 2.65 & 1.85 & 3.15 \\
\hline 6 & $70(0)$ & $2.5(+1)$ & 5 & 1.47 & 3.15 & 2.15 & 3.50 \\
\hline 7 & $100(+1)$ & $0.5(-1)$ & 1 & 0.66 & 1.95 & 0.77 & 2.15 \\
\hline 8 & $100(+1)$ & $1.5(0)$ & 3 & 0.91 & 2.3 & 1.65 & 2.75 \\
\hline 9 & $100(+1)$ & $2.5(+1)$ & 5 & 1.33 & 2.9 & 1.95 & 3.05 \\
\hline 10 & $70(0)$ & $1.5(0)$ & 3 & 1.05 & 2.45 & 2.05 & 3.05 \\
\hline 11 & $70(0)$ & $1.5(0)$ & 3 & 1.22 & 2.60 & 1.73 & 2.95 \\
\hline 12 & $70(0)$ & $1.5(0)$ & 3 & 1.35 & 2.73 & 1.92 & 3.10 \\
\hline 13 & $70(0)$ & $1.5(0)$ & 3 & 1.17 & 2.40 & 1.80 & 3.23 \\
\hline
\end{tabular}

$\mathrm{CO}_{2}$ uptake capacity and breakthrough time exhibit acceptable values for the standard deviation, $R^{2}$, and $A d j-R^{2}$ which indicate that the considered values fit properly the developed models, and they have an excellent capacity to predict the response surfaces under other required operational conditions.

On the other hand, by evaluation of coded coefficients, it can be revealed that the linear coefficients exert stronger effects on the adsorption process than other ones, by having -0.34 and 0.41 for $\left(Q_{\mathrm{CO} 2}\right)_{\mathrm{CMSW}-800 \mathrm{~S}}$, -0.29 and 0.51 for $\left(t_{\mathrm{b}}\right)_{\mathrm{CMSW}-800 \mathrm{~S}},-0.33$ and 0.61 for $\left(Q_{\mathrm{CO} 2}\right)_{\mathrm{CMSW}-\mathrm{S} 800}$, and -0.41 and 0.51 for $\left(t_{\mathrm{b}}\right)_{\mathrm{CMSW}-\mathrm{S} 800}$ responses, respectively, for linear temperature and pressure coefficients. Furthermore, it can be stated that among the linear variables the adsorption pressure is the determinative one. Here, the negative values of the linear coefficients of temperature $(-0.34,-0.29$, -0.33 , and -0.41 for $\left(Q_{\mathrm{CO} 2}\right)_{\mathrm{CMSW}-800 \mathrm{~S}}$ $\left(t_{\mathrm{b}}\right)_{\mathrm{CMSW}-800 \mathrm{~S}}, \quad\left(Q_{\mathrm{CO} 2}\right)_{\mathrm{CMSW}-\mathrm{S} 800}, \quad$ and $\left(t_{\mathrm{b}}\right)_{\mathrm{CMSW}-\mathrm{S} 800}$ responses, respectively) express a negative effect of temperature increase, while the positive values of pressure, in accordance with the Le Chatelier's

According to the ANOVA results (Tabs. 8 and 9), all developed models are statistically significant, since the $p$ value is $<0.0001$, by having non-significant lack of fits, which are the main factors of an authentic model. The proposed models for principle, illustrate the constructive effect of pressure increment on the adsorption process.

In addition, the ANOVA results demonstrate that the interaction effects of $\left(Q_{\mathrm{CO} 2}\right)_{\mathrm{CMSW}-800 \mathrm{~s}}$ are significant (coded coeffi- 
Table 8. Analysis of variance (ANOVA) of $\mathrm{CCD}$ for $\mathrm{CO}_{2}$ adsorption and breakthrough time on CMSW-800-S.

\begin{tabular}{|c|c|c|c|c|c|c|}
\hline & $\begin{array}{l}\text { Coded } \\
\text { coefficient }\end{array}$ & $\begin{array}{l}\text { Standard } \\
\text { error }\end{array}$ & $\begin{array}{l}\text { Sum of } \\
\text { squares }\end{array}$ & $\begin{array}{l}\text { Mean } \\
\text { squares }\end{array}$ & $\mathrm{df}$ & $p$ value \\
\hline \multicolumn{7}{|c|}{$\mathrm{CO}_{2}$ uptake capacity $\mathrm{Q}\left[\mathrm{mmolg}^{-1}\right]$} \\
\hline Model & & & 1.81 & 0.36 & 5 & 0.0001 \\
\hline$T$ & -0.34 & 0.044 & 0.70 & 0.70 & 1 & 0.0001 \\
\hline$P_{\mathrm{CO} 2}$ & 0.41 & 0.044 & 1.00 & 1.00 & 1 & $<0.0001$ \\
\hline$T P_{\mathrm{CO} 2}$ & -0.11 & 0.054 & 0.046 & 0.046 & 1 & 0.0857 \\
\hline$T^{2}$ & 0.15 & 0.065 & 0.066 & 0.066 & 1 & 0.0485 \\
\hline$P_{\mathrm{CO} 2}^{2}$ & -0.046 & 0.065 & 0.005 & 0.005 & 1 & 0.5029 \\
\hline Residual & & & 0.081 & 0.012 & 7 & \\
\hline Lack-of-fit & & & 0.033 & 0.011 & 3 & 0.5108 \\
\hline Pure error & & & 0.048 & 0.012 & 4 & \\
\hline Total & & & 1.89 & & 12 & \\
\hline Std. dev. & 0.11 & & & & & \\
\hline$R^{2}$ & 0.957 & & & & & \\
\hline $\operatorname{Adj}-R^{2}$ & 0.927 & & & & & \\
\hline \multicolumn{7}{|c|}{ Breakthrough time $t_{b}[\mathrm{~min}]$} \\
\hline Model & & & 2.08 & 0.42 & 5 & $<0.0001$ \\
\hline$T$ & -0.29 & 0.045 & 0.49 & 0.49 & 1 & 0.0004 \\
\hline$P_{\mathrm{CO} 2}$ & 0.51 & 0.043 & 1.56 & 1.56 & 1 & $<0.0001$ \\
\hline $\mathrm{TP}_{\mathrm{CO} 2}$ & -0.015 & 0.056 & 0.0009 & 0.0009 & 1 & 0.7949 \\
\hline$T^{2}$ & 0.074 & 0.067 & 0.015 & 0.015 & 1 & 0.3051 \\
\hline$P_{\mathrm{CO} 2}^{2}$ & 0.049 & 0.066 & 0.007 & 0.007 & 1 & 0.4876 \\
\hline Residual & & & 0.086 & 0.012 & 7 & - \\
\hline Lack-of-fit & & & 0.01 & 0.003 & 3 & \\
\hline Pure error & & & 0.076 & 0.019 & 4 & \\
\hline Total & & & 2.17 & & 12 & \\
\hline Std. dev. & 0.11 & & & & & \\
\hline$R^{2}$ & 0.960 & & & & & \\
\hline $\operatorname{Adj}-R^{2}$ & 0.932 & & & & & \\
\hline
\end{tabular}

$$
\begin{aligned}
\left(Q_{\mathrm{CO}_{2}}\right)_{\mathrm{CMSW}-800 \mathrm{~S}}= & 1.73+0.796 P \\
& -0.03 T \\
& -(0.0035 P T) \\
& +0.00017 T^{2}
\end{aligned}
$$

$$
\begin{aligned}
\left(t_{\mathrm{b}}\right)_{\mathrm{CMSW}-800 \mathrm{~S}}= & 2.92+0.398 P \\
& -0.02 \mathrm{~T}
\end{aligned}
$$

In a same trend, the evaluation of second-order coefficients of the CMSW-S-800 sample illustrates that the adsorption temperature is not statistically significant in $Q$ and $t_{\mathrm{b}}$ models ( $p$ value 0.1875 and 0.2786 for $\left(Q_{\mathrm{CO} 2}\right)_{\mathrm{CMSW}-\mathrm{S} 800}$ and $\left(t_{\mathrm{b}}\right)_{\mathrm{CMSW}-\mathrm{S} 800}$, respectively); thus, to increase the confidence level of the obtained models to more than 0.95 , these terms can be eliminated from Eqs. (14) and (15), and they are also simplified as:

$$
\begin{aligned}
\left(Q_{\mathrm{CO}_{2}}\right)_{\mathrm{CMSW}-\mathrm{S} 800}= & 1.59+1.426 P \\
& -0.025 T \\
& -0.247 P^{2}
\end{aligned}
$$

$$
\begin{aligned}
\left(t_{\mathrm{b}}\right)_{\mathrm{CMSW}-\mathrm{S} 800}= & 3.069+1.136 P \\
& -0.02 T-0.163 P^{2}
\end{aligned}
$$

To describe the characteristics of the adsorption systems, the obtained results of the CCD models for the CMSW-800-S and CMSW-S-800 samples are depicted in Figs. 7 and 8. As can be expected, the uptake capacity of both samples was improved by increasing the adsorption pressure (Figs. $7 \mathrm{a}$ and $8 \mathrm{a}$ ), while the temperature increment had a negative

cients: $-0.11, p$ value: 0.0857 , while this parameter is negligible for other response surfaces (including $-0.015,-0.03$, and

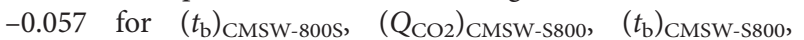
respectively). Also, the analysis of second-order coefficients for the CMSW-800-S sample indicates that the temperature is the only significant parameter for $\mathrm{CO}_{2}$ capture capacity, and the other ones are negligible to achieving models with more than 0.95 confidence levels. Thus, Eqs. (12) and (13) can be simplified as: effect on the adsorption process. A same trend can be observed for the breakthrough time (Figs. $7 \mathrm{~b}$ and $8 \mathrm{~b}$ ). On the other hand, as can be observed, the breakthrough time of the CMSW-800-S sample has (almost) a linear behavior according to the significant order of the different variables (ANOVA results). 
Table 9. Analysis of variance (ANOVA) of $\mathrm{CCD}$ for $\mathrm{CO}_{2}$ adsorption and breakthrough time on CMSW-S-800.

\begin{tabular}{|c|c|c|c|c|c|c|}
\hline & $\begin{array}{l}\text { Coded } \\
\text { coefficient }\end{array}$ & $\begin{array}{l}\text { Standard } \\
\text { error }\end{array}$ & $\begin{array}{l}\text { Sum of } \\
\text { squares }\end{array}$ & $\begin{array}{l}\text { Mean } \\
\text { squares }\end{array}$ & $\mathrm{df}$ & $p$ value \\
\hline \multicolumn{7}{|c|}{$\mathrm{CO}_{2}$ uptake capacity $\mathrm{Q}\left[\mathrm{mmolg}^{-1}\right]$} \\
\hline Model & & & 3.08 & 0.62 & 5 & $<0.0001$ \\
\hline$T$ & -0.33 & 0.048 & 0.65 & 0.65 & 1 & 0.0002 \\
\hline$P_{\mathrm{CO} 2}$ & 0.61 & 0.048 & 2.26 & 2.26 & 1 & $<0.0001$ \\
\hline$T P_{\mathrm{CO} 2}$ & -0.03 & 0.058 & 0.003 & 0.003 & 1 & 0.6225 \\
\hline$T^{2}$ & 0.10 & 0.070 & 0.029 & 0.029 & 1 & 0.1875 \\
\hline$P_{\mathrm{CO} 2}^{2}$ & -0.25 & 0.070 & 0.17 & 0.17 & 1 & 0.0096 \\
\hline Residual & & & 0.095 & 0.014 & 7 & \\
\hline Lack-of-fit & & & 0.035 & 0.012 & 3 & 0.5610 \\
\hline Pure error & & & 0.060 & 0.015 & 4 & \\
\hline Total & & & 3.18 & & 12 & \\
\hline Std. dev. & 0.12 & & & & & \\
\hline$R^{2}$ & 0.971 & & & & & \\
\hline $\operatorname{Adj}-R^{2}$ & 0.948 & & & & & \\
\hline \multicolumn{7}{|c|}{ Breakthrough time $t_{b}[\mathrm{~min}]$} \\
\hline Model & & & 2.68 & 0.54 & 5 & $<0.0001$ \\
\hline$T$ & -0.41 & 0.036 & 1.02 & 1.02 & 1 & $<0.0001$ \\
\hline$P_{\mathrm{CO} 2}$ & 0.51 & 0.036 & 1.58 & 1.58 & 1 & $<0.0001$ \\
\hline$T P_{\mathrm{CO} 2}$ & -0.057 & 0.044 & 0.013 & 0.013 & 1 & 0.2329 \\
\hline$T^{2}$ & 0.062 & 0.053 & 0.011 & 0.011 & 1 & 0.2786 \\
\hline$P_{\mathrm{CO} 2}^{2}$ & -0.16 & 0.053 & 0.073 & 0.073 & 1 & 0.0180 \\
\hline Residual & & & 0.054 & 0.007 & 7 & - \\
\hline Lack-of-fit & & & 0.009 & 0.003 & 3 & \\
\hline Pure error & & & 0.044 & 0.011 & 4 & \\
\hline Total & & & 2.74 & & 12 & \\
\hline Std. dev. & 0.088 & & & & & \\
\hline$R^{2}$ & 0.981 & & & & & \\
\hline $\operatorname{Adj-R^{2}}$ & 0.966 & & & & & \\
\hline
\end{tabular}

\section{Conclusion}

The potential of compost derived from municipal solid wastes as a low-cost source of adsorbents for $\mathrm{CO}_{2}$ capture was investigated. Five different samples were synthesized and screened regarding the $\mathrm{CO}_{2}$ uptake. The breakthrough results showed that the CMSW-S-800, which was chemically treated by sulfuric acid and thermally activated at $800{ }^{\circ} \mathrm{C}$, had the highest breakthrough time of around $4 \mathrm{~min}$ and its adsorption capacity was $2.5 \mathrm{mmol} \mathrm{g}^{-1}$ at $2.5 \mathrm{bar}$ and $40^{\circ} \mathrm{C}$ (around $11 \mathrm{wt} \%$ ), which is in the range of commercial carbon materials.

In the next step, statistical analysis and adsorption performance of the best samples were performed by means of the CCD technique and RSM strategy. It revealed that the $\mathrm{CO}_{2}$ partial pressure and the adsorption temperature are the main factors in the adsorption process. Finally, by considering the worldwide abundance of municipal solid wastes, this study can be considered as a green route for the solid wastes management and carbon capture and storage.

\section{Acknowledgment}

This work was financially supported by: Project POCI-01-0145FEDER-006984 - Associate Laboratory LSRE-LCM funded by FEDER through COMPETE2020 Programa Operacional Competitividade e Internacionalização (POCI) and project VALORCOMP (ref. 0119_VALORCOMP_2_P), financed through INTERREG $\mathrm{V}$ A Spain Portugal (POCTEP) 20142020 by national funds through FCT, and Project NORTE-01-0145FEDER-000006, supported by Norte's Regional Operational Programme (NORTE 2020), under the Portugal 2020 Partnership Agreement, through the European Regional Development Fund, and by CIMO under UID/AGR/00690/ 2019. Mohsen Karimi acknowledges research grant awarded under Project: SFRH/BD/140550/2018 by Foundation for Science and Technology (FCT, Portugal).

The authors have declared no conflict of interest.

\section{Supporting Information}

Supporting Information for this article can be found under DOI: https://doi.org/10.1002/ceat.201900108. 

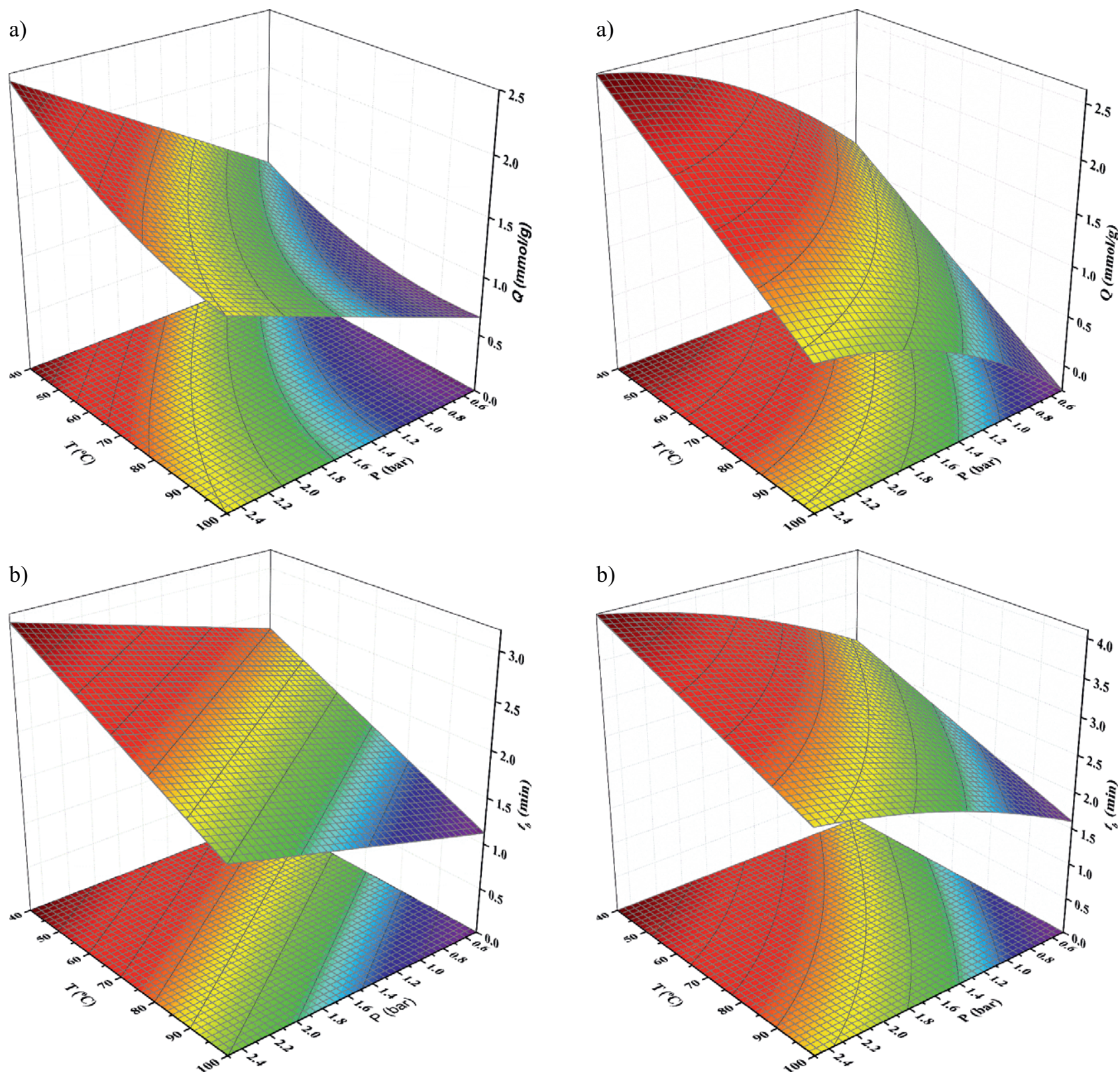

Figure 7. Response surface of (a) $\mathrm{CO}_{2}$ uptake capacity of CMSW$800-S$ sample, (b) breakthrough time $\left(t_{\mathrm{b}}\right)$ as a function of adsorption pressure and temperature.

Figure 8. Response surface of (a) $\mathrm{CO}_{2}$ uptake capacity of CMSW$\mathrm{S}-800$ sample, (b) breakthrough time $\left(t_{\mathrm{b}}\right)$ as a function of adsorption pressure and temperature.

\section{Symbols used}

\begin{tabular}{|c|c|}
\hline$D_{\text {microp }}$ & {$[\mathrm{mm}]$} \\
\hline$F_{\mathrm{CO}_{2, \text { in }}}$ & {$\left[\mathrm{mL} \mathrm{min} \min ^{-1}\right]$} \\
\hline$F_{\mathrm{CO}_{2, \text { out }}}$ & {$\left[\mathrm{mL} \mathrm{min} \min ^{-1}\right]$} \\
\hline$\Delta H$ & {$\left[\mathrm{~kJ} \mathrm{~mol}^{-1}\right]$} \\
\hline$K_{\mathrm{L}}$ & {$\left[\mathrm{bar}^{-1}\right.$ ] } \\
\hline$K_{\infty}$ & {$\left[\mathrm{bar}^{-1}\right.$ ] } \\
\hline
\end{tabular}

average pore diameter

molar flow rate of $\mathrm{CO}_{2}$ at the bed inlet

molar flow rate of $\mathrm{CO}_{2}$ at the bed outlet

heat of adsorption

Langmuir adsorption constant

affinity constant

$\begin{array}{ll}M & {\left[\mathrm{~g} \mathrm{mmol}^{-1}\right]} \\ m_{\text {adsorbent }} & {[\mathrm{g}]} \\ P_{\mathrm{b}} & {[\mathrm{bar}]} \\ P_{\mathrm{CO} 2} & {[\mathrm{bar}]} \\ Q_{\mathrm{e}} & {\left[\mathrm{mmol} \mathrm{g}{ }^{-1}\right]} \\ & \\ Q_{\mathrm{m}} & {\left[\mathrm{mmol} \mathrm{g}^{-1}\right]} \\ S_{\mathrm{BET}} & {\left[\mathrm{m}^{2} \mathrm{~g}^{-1}\right]} \\ S_{\text {ext }} & {\left[\mathrm{m}^{2} \mathrm{~g}^{-1}\right]} \\ S_{\mathrm{Mic}} & {\left[\mathrm{m}^{2} \mathrm{~g}^{-1}\right]} \\ t_{\mathrm{b}} & {[\mathrm{min}]}\end{array}$

molecular weight

mass of adsorbent in the bed pressure of bed at equilibrium partial pressure of $\mathrm{CO}_{2}$ adsorption capacity at equilibrium condition

maximum adsorption capacity specific surface area external surface area microporous surface area breakthrough time 


$\begin{array}{ll}t_{\mathrm{s}} & {[\mathrm{min}]} \\ T_{\mathrm{b}} & {[\mathrm{K}]} \\ V_{\mathrm{b}} & {\left[\mathrm{cm}^{3}\right]} \\ V_{\mathrm{d}} & {\left[\mathrm{cm}^{3}\right]} \\ V_{\text {Mic }} & {\left[\mathrm{mm}^{3} \mathrm{~g}^{-1}\right]} \\ V_{\text {Total }} & {\left[\mathrm{mm}^{3}\right]} \\ W_{\text {Mic }} & {[\mathrm{nm}]} \\ y_{\mathrm{CO}_{2, \text { feed }}} & {[-]} \\ Z & {[-]}\end{array}$

saturation time temperature of bed at equilibrium bed volume

dead volume

micropore volume

total pore volume

width of micropore

molar fraction of $\mathrm{CO}_{2}$ in feed stream $\mathrm{CO}_{2}$ compressibility factor at $P_{\mathrm{b}}$ and $T_{\mathrm{b}}$

\section{Greek letters}

$\begin{array}{lll}\alpha & {[-]} & \text { sticking coefficient } \\ \varepsilon & {[-]} & \text { residual error } \\ \varepsilon_{\mathrm{b}} & {[-]} & \text { packed bed porosity } \\ \varepsilon_{\mathrm{p}} & {[-]} & \text { particle porosity } \\ \varepsilon_{\mathrm{T}} & {[-]} & \text { total porosity of bed }\end{array}$

\section{Subscripts and superscripts}

Ads. adsorbent

min minute

Tot total

\section{Abbreviations}

ANOVA analysis of variance

BET Brunauer-Emmett-Teller

CCD central composite design

GHG greenhouse gas

IME integrated management of environment

MSW municipal solid waste

MTZ mass transfer zone

RSM response surface methodology

TCD thermal conductivity detector

TGA thermogravimetric analysis

\section{References}

[1] M. Karimi, M. R. Rahimpour, R. Rafiei, M. Jafari, D. Iranshahi, A. Shariati, J. Nat. Gas Sci. Eng. 2014, 17, 136150.

[2] $\mathrm{CO}_{2}$ Emissions from Fuel Combustion, International Energy Agency (IEA), Paris 2014. DOI: https://doi.org/10.1787/ co2_fuel-2014-en

[3] Climate Change 2013: The Physical Science Basis. Contribution of Working Group I to the Fifth Assessment Report of the Intergovernmental Panel on Climate Change (Eds: T. F. Stocker, D. Qin, G. K. Plattner, M. Tignor, S. K. Allen, J. Boschung, A. Nauels, Y. Xia, V. Bex, P. M. Midgley), Cambridge University Press, New York 2013.

[4] D. Iranshahi, M. Karimi, S. Amiri, M. Jafari, R. Rafiei, M. R. Rahimpour, Chem. Eng. Res. Des. 2014, 92 (9), 17041727.
[5] M. Karimi, M. R. Rahimpour, D. Iranshahi, Chem. Eng. Technol. 2018, 41 (9), 1746-1758.

[6] M. Karimi, M. R. Rahimpour, R. Rafiei, A. Shariati, D. Iranshahi, Appl. Therm. Eng. 2016, 94, 543-558.

[7] M. Shirzad, M. Karimi, J. A. C. Silva, A. E. Rodrigues, Ind. Eng. Chem. Res. 2019, 58 (22), 9179-9198.

[8] C. Zhao, X. Chen, C. Zhao, Energy Fuels 2012, 26, 14011405.

[9] M. Karimi, J. A. C. Silva, C. N. d. P. Gonçalves, J. L. Diaz de Tuesta, A. E. Rodrigues, H. T. Gomes, Ind. Eng. Chem. Res. 2018, 57 (32), 11154-11166.

[10] J. A. Mason, T. M. McDonald, T. H. Bae, J. E. Bachman, K. Sumida, J. J. Dutton, S. S. Kaye, J. R. Long, J. Am. Chem. Soc. 2015, 137 (14), 4787-4803.

[11] R. Wennersten, Q. Sun, H. Li, J. Cleaner Prod. 2014, 103, 724-736.

[12] T. Karak, R. M. Bhagat, P. Bhattacharyya, Crit. Rev. Environ. Sci. Technol. 2012, 42 (15), 1509-1630.

[13] Solid Waste Management, United Nations Environment Program (Eds: L. F. Diaz, P. Bakken), Vol. I, CalRecovery, Inc., Concord, CA 2005.

[14] A Global Snapshot of Solid Waste Management to 2050 (Eds: S. Kaza, L. Yao, P. Bhada-Tata, F. V. Woerden), The World Bank, Washington, D.C. 2018.

[15] Handbook of Solid Waste Management (Eds: G. Tchobanoglous, F. Kreith), 2nd ed. McGraw Hill, New York 2002.

[16] S. Brunauer, P. H. Emmett, E. Teller, J. Am. Chem. Soc. 1938, 60 (2), 309-319.

[17] B. C. Lippens, J. H. de Boer, J. Catal. 1965, 4, 319-323.

[18] J. A. C. Silva, K. Schumann, A. E. Rodrigues, Microporous Mesoporous Mater. 2012, 158, 219-228.

[19] J. M. Becnel, C. E. Holland, J. McIntyre, M. A. Matthews, J. A. Ritter, American Society for Engineering Education Annual Conference \& Exposition, Montréal, QC 2002.

[20] J. A. C. Silva, A. E. Rodrigues, Chem. Eng. Technol. 2015, 38 (12), 2335-2339.

[21] I. Langmuir, J. Am. Chem. Soc. 1916, 38 (11), 2221-2295.

[22] Response Surface Methodology: Process and Product Optimization Using Designed Experiments (Eds: R. H. Myers, D. C. Montgomery, C. M. Anderson-Cook), 4th ed. John Wiley \& Sons, Hoboken, NJ 2016.

[23] S. García, M. V. Gil, J. J. Pis, F. Rubiera, C. Pevida, Int. J. Greenhouse Gas Control 2013, 12, 35-43.

[24] T. Z. E. Lee, C. Krongchai, N. A. L. M. Irwn Lu, S. Kittiwachana, S. F. Sim, Int. J. Ind. Chem. 2015, 6, 185-191.

[25] Unit Operations of Chemical Engineering (Eds: W. L. McCabe, J. C. Smith, P. Harriott), 7th ed. McGraw-Hill, New York 2005

[26] L. K. G. Bhatta, S. Subramanyam, M. D. Chengala, S. Olivera, K. Venkatesh, J. Cleaner Prod. 2015, 103, 171-196.

[27] S. Shahkarami, R. Azargohar, A. K. Dalai, J. Soltan, J. Environ. Sci. 2015, 34, 68-76.

[28] C. Tangsathitkulchai, S. Junpirom, J. Katesa, J. Nanomater. 2016, 2016, 4292316.

[29] I. Durán, N. Álvarez-Gutiérrez, F. Rubiera, C. Pevida, Chem. Eng. J. 2018, 353, 197-207.

[30] A. R. Nabais, R. P. P. L. Ribeiro, J. P. B. Mota, V. D. Alves, I. A. A. C. Esteves, L. A. Neves, Sep. Purif. Technol. 2018, 202, 174-184. 
[31] S. García, M. V. Gil, C. F. Martín, J. J. Pis, F. Rubiera, C. Pevida, Chem. Eng. J. 2011, 171, 549-556.

[32] A. Henrique, M. Karimi, J. A. C. Silva, A. E. Rodrigues, Chem. Eng. Technol. 2019, 42 (2), 327-342.

[33] S. Khalili, B. Khoshandam, M. Jahanshahi, RSC Adv. 2015, 5, 94115-94129.

[34] N. Álvarez-Gutiérrez, M. V. Gil, F. Rubiera, C. Pevida, Fuel Process. Technol. 2016, 142, 361-369.

[35] Z. Zhang, K. Wang, J. D. Atkinson, X. Yan, X. Li, M. J. Rood, Z. Yan, J. Hazard. Mater. 2012, 229, 183-191.

[36] Y. Zhao, Y. Shen, L. Bai, S. Ni, Appl. Surf. Sci. 2012, 261, 708-716. 
Research Article: The potential of compost derived from municipal solid wastes as a low-cost source of adsorbents for $\mathrm{CO}_{2}$ capture was investigated. Five different samples were synthesized and screened regarding $\mathrm{CO}_{2}$ uptake. One sample, which was chemically treated by sulfuric acid and thermally activated at $800^{\circ} \mathrm{C}$, had the highest breakthrough time and an adsorption capacity comparable to commercial carbon materials.
Compost from Municipal Solid Wastes as a Source of Biochar for $\mathrm{CO}_{2}$ Capture

M. Karimi* J. L. Diaz de Tuesta,

C. N. d. P. Gonçalves, H. T. Gomes,

A. E. Rodrigues, J. A. C. Silva*

Chem. Eng. Technol. 2020, 43 (XX),

$\mathrm{XXX} \ldots \mathrm{XXX}$

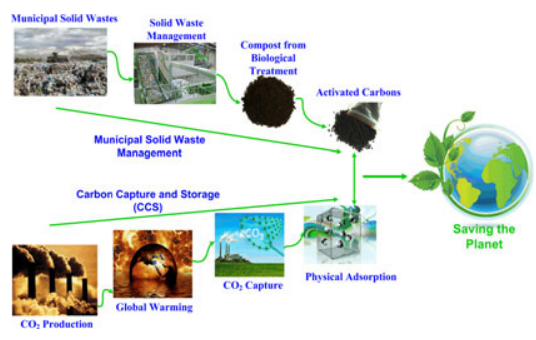

DOI: 10.1002/ceat.201900108

Supporting Information

available online 